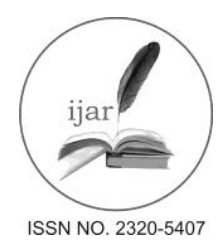

\section{Journal homepage:http://www.journalijar.com Journal DOI:10.21474/IJAR01}

\section{RESEARCH ARTICLE}

INTERNATIONAL JOURNAL

OF ADVANCED RESEARCH

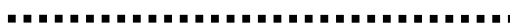

\title{
USE OF INTERNET AND ITS EFFECTS ON ADOLESCENTS.
}

\author{
Pratima Tiwari $^{1}$, Dr. Indira Bishnoi ${ }^{2}$, PratimaSachan ${ }^{3}$. \\ 1. Research Scholar, Department of Home Science, Extension and Communication,Banaras Hindu University, \\ Varanasi. \\ 2. Head of Department, Department of Home Science, Extension and Communication,Banaras Hindu University, \\ Varanasi.
}

\section{Manuscript Info}

\section{Manuscript History:}

Received: 18 March 2016

Final Accepted: 22 April 2016

Published Online: May 2016

Key words:

Internet,Adolescents,Effects,Time, Uses

*Corresponding Author

Pratima Tiwari.

\section{Abstract}

This research paper aimed at to look the use of internet and its effects on adolescents. Internet plays an important role in our lives. It provide us with a method to connect to important others in our lives.this study was conducted to establish the kinds of activities that adolescents performed on the internet and length of the time they spend on the internet in order to know the effects of internet on adolescents. The study was conducted on 100 adolescents comprising 50 boys and 50 girls of Guru Nanak Academy school of faizabad. The result revealed that boys used more internet as compare to girls. There is both positive and negative effects of internet on girls and boys. Boys had spend more time on internet than girls. Adolescents engage in internet chat rooms and reveal their personal information to people they meet online. The positive impact of Internet includes increase in knowledge, awareness and gain of more confidence. The negative aspects of the Internet include Internet addiction as well as online risks such as exposure to sexually explicit material and online victimization including harassment or cyber bullying and sexual solicitation.

Copy Right, IJAR, 2016... All rights reserved.

\section{Introduction:-}

Access to, and use of, the Internet has increased drastically between year 2000 to 2013 . According to the statistics, the number of people with Internet access has grown to over 250 billion in 2013. South Africa is one of the leading countries with internet access and had more than 5 million internet user by September 2006.

In the age of the Internet and other new media technologies, change has occurred not only in the technology itself, but also in how individuals interact, define, and organize their world. People of all ages are in various stages of transition in regard to the use of new media technology. Adolescents are able to embrace and utilize these technologies with less effort than adults, including their parents. Adolescents may not recall how or when they learned to use a computer or access the Internet; for as long as they can remember, those tools were always there. Growing up in a world of constantly evolving technology is unique to adolescents as a whole because they have known nothing else. Hence, using new media is not a consciously learned experience for adolescents. It is an acquired skill, similar to that of a child learning to speak his native tongue. The prevalence of new media within the home and school impacts the way a student learns and interacts with teachers, parents, and peers. In this technological age, adolescents rely on the Internet for entertainment and educational resources. But, despite their prowess in using new media, they may lack imagination and basic skills such how to use a dictionary or thesaurus. The Internet is not only accessed at homes but also school and Internet cafe's.

There is a great Varity of content that can be accessed on the Internet. The content can be about something harmful. The main issue of concern is that Internet content is often not classified. The content that adolescents search for ranges from downloadable cell phone ringtones, to social networking websites. Some content may not be safe for 
adolescent to view. For instance having access to information which can teach adolescents to make an explosive could pose a danger to society. In essence the content that the learners view on the Internet is important because It has the power to influence the adolescents knowledge and decisions.

Thus the present study was designed with the following objectives:

1. To find out the prevalence of Internet use among adolescents.

2. To study about how much time adolescents spend on internet for different activities.

3. To study the positive and negative effects of Internet on adolescents.

\section{Methodology:-}

Questionnaire was used for collection of data. Adolescents in the age group of 17-19 years were selected from Guru Nanak Academy School of Faizabad city using simple random sampling and purposive sampling. The total sample of 100 adolescents comprising 50 boys and 50 girls were selected for the present study. The data collected was then analyzed to draw appropriate inferences by application of suitable statistical techniques. The statistical methods used were Percentage and Chi- square test.

\section{Results and discussion:-}

The findings of the study were discussed under following points.

1. Distribution of respondents according to ever use of internet.

2. Distribution of respondents according to time spend per week on Internet for studying.

3. Distribution of respondents according to time spend per week on Internet for Entertainment, News, \& Information.

4. Distribution of respondents according to ever use of any Social Networking Sites.

5. Distribution of respondents who feel that internet is a good way for socialization.

6. Distribution of respondents who feel that internet have positive or negative effect

Table no:1:- Distribution of respondents according to ever use of internet.

\begin{tabular}{|c|c|c|c|c|}
\hline Internet use & Female & Percentage & Male & Percentage \\
\hline Yes & 40 & $80 \%$ & 48 & $96 \%$ \\
\hline No & 10 & $20 \%$ & 2 & $4 \%$ \\
\hline Total & 50 & $100 \%$ & 50 & $100 \%$ \\
\hline
\end{tabular}

Tabulated value 0.00393

Degree of freedom: 1

calculated value 0.108698541

From the above table it is clear that calculated value is greater than the tabulated Value at 0.05 level of significance at 1 degree of freedom. Hence Null Hypothesis is rejected. Thus we can say that there is significant difference between male and female internet use.

Table no: 2:-Distribution of respondents according to time spend per week on Internet for studying.

\begin{tabular}{|c|c|c|c|c|}
\hline Time duration & Female & Percentage & Male & Percentage \\
\hline 3-6 hours & 37 & $74 \%$ & 38 & $76 \%$ \\
\hline $7-15$ hours & 8 & $16 \%$ & 12 & $24 \%$ \\
\hline 16 hours and longer & 5 & $10 \%$ & 0 & $0 \%$ \\
\hline Total & 50 & $100 \%$ & 50 & $100 \%$ \\
\hline
\end{tabular}

The table shows that maximum $74 \%$ of female respondents spend 3-6 hours per week on internet for studying purpose while $76 \%$ of male respondents spend 3-6 hours per week on internet for studying purpose. 
Table no: 3:- Distribution of respondents according to time spend per week on Internet for Entertainment, News, \& Information.

\begin{tabular}{|c|c|c|c|c|}
\hline Time duration & Female & Percentage & Male & Percentage \\
\hline 3-6 hours & 37 & $74 \%$ & 38 & $76 \%$ \\
\hline 7-15 hours & 8 & $16 \%$ & 12 & $24 \%$ \\
\hline 16 hours and larger & 5 & $10 \%$ & 0 & 0 \\
\hline Total & 50 & $100 \%$ & 50 & $100 \%$ \\
\hline
\end{tabular}

The table indicates that $74 \%$ of female respondents were agreed that they had to spend 3-6 hours on internet for entertainment, news and information purpose per week while $76 \%$ of male respondents were agreed that they had to spend 3-6 hours on internet for entertainment, news and information purpose per week.

Table no:4:- Distribution of respondents according to ever use of any Social Networking Sites.

\begin{tabular}{|c|c|c|c|c|}
\hline Category & Female & Percentage & Male & Percentage \\
\hline Yes & 40 & $80 \%$ & 50 & $100 \%$ \\
\hline No & 10 & $20 \%$ & 0 & $0 \%$ \\
\hline Total & 50 & $100 \%$ & 50 & $100 \%$ \\
\hline
\end{tabular}

The table reveals that $80 \%$ of female respondents ever visited on any social networking sites while $100 \%$ of male respondents ever visited on any social networking sites.

\begin{tabular}{|c|c|c|}
\hline Tabulated value & df & calculated value \\
\hline $\mathbf{0 . 0 0 3 9 3}$ & $\mathbf{1}$ & 0.01113998 \\
\hline
\end{tabular}

\section{Interpretation:-}

From the above table it is clear that calculated value is greater than the tabulated Value at 0.05 level of significance at 1 degree of freedom. Hence Null Hypothesis is rejected. Thus we can say that there is significant difference between male and female social networking sites use.

Table no: 5:- Distribution of respondents who feel that internet is a good way for socialization.

\begin{tabular}{|c|c|c|c|c|}
\hline Socialization & Female & Percentage & Male & Female \\
\hline Yes & 38 & $76 \%$ & 40 & $80 \%$ \\
\hline No & 12 & $24 \%$ & 10 & $20 \%$ \\
\hline Total & 50 & $100 \%$ & 50 & $100 \%$ \\
\hline
\end{tabular}

The table shows that maximum $76 \%$ of female respondents feel that internet is a good way for socialization while maximum $80 \%$ of male respondents feel that internet is a good way for socialization.

\begin{tabular}{|l|l|l|}
\hline Tabulated value & Df & Calculated value \\
\hline $\mathbf{0 . 0 0 3 9 3}$ & $\mathbf{1}$ & $\mathbf{0 . 9 7 2 0 7 6 7 7 5}$ \\
\hline
\end{tabular}

\section{Interpretation:-}

From the above table it is clear that calculated value is greater than the tabulated Value at 0.05 level of significance at 1 degree of freedom. Hence Null Hypothesis is rejected. Thus we can say that there is significant difference between male and female who feel that internet is a good way of socialization.

Table no: 6:- Distribution of respondents who feel that internet have positive or negative effect.

\begin{tabular}{|c|c|c|c|c|}
\hline Effect & Female & Percentage & Male & Percentage \\
\hline Positive & 33 & $66 \%$ & 38 & $76 \%$ \\
\hline Negative & 17 & $34 \%$ & 12 & $24 \%$ \\
\hline Total & 50 & $100 \%$ & 50 & $100 \%$ \\
\hline
\end{tabular}

\begin{tabular}{|l|l|l|}
\hline Tabulated value & Degree of freedom & Calculated value \\
\hline $\mathbf{0 . 0 0 3 9 3}$ & $\mathbf{1}$ & 0.749605021 \\
\hline
\end{tabular}




\section{Interpretation:-}

From the above table it is clear that calculated value is greater than the tabulated Value at 0.05 level of significance at 1 degree of freedom. Hence Null Hypothesis is rejected. Thus we can say that there is significant difference between male and female feel of impact of internet.

\section{Conclusion:-}

The findings indicated that boys reported to have a higher uses of internet as compare to girls and boys spend more time on internet for different activities than girls. It also revealed that both boys and girls believed that internet has both positive and negative effect. The positive impact of Internet includes increase in knowledge, awareness and gain of more confidence. The negative aspects of the Internet include Internet addiction as well as online risks such as exposure to sexually explicit material and online victimization including harassment or cyber bullying and sexual solicitation.

\section{Suggestions:-}

1. There is a need of formal training for internet use, need of high bandwidths far speedy data transmission.

2. Internet services providers should come forward to give internet facility studies on the scenario

3. Ii is required for Internet users to know its latest trend and development for

4. Effective satisfaction of information needs.

5. Websites providing only entertainment should be locked so that users should not unnecessarily sit on computers.

6. To avoid difficulty in accessing information at peak hours the timing of the

7. Internet service should be extending round the clock.

8. Users should have the awareness of different search engines.

\section{References:-}

1. Beebe, T.J, Asche, S.E. Harrison, P.A, and Quintan, K.B.2004, Heightened vulnerability and increased risk taking among adolescent chat room users. Journal of Adolescent Health, 35:16-123.

2. Borzekowski, D.L.G. \&Rickert, V.I. 2005 ADOLESCENTS, the Internet. And health issues of access and content. Applied Developmental Psychology, 22: 49-59.

3. Christopherson, K.M.2006 the positive and negative implications of anonymity in Internet social interactions. Computers in Human Behavior,23:3038-3056

4. Danah, 2011.The functions of Internet use and their social and psychological consequences.Cyberpsychology\& Behavior, 4(6), 723-743. Retrieved May 3, 2008, from http://web.ebscohost.com

5. Grinter, Rebecca E. \& Eldridge, Margery (2006). Wan2tlk?: Everyday text messaging. CHI 2003: New Horizons, 5(1), 441-448.

6. Gross, Elisheva F.; Juvonen, Jaana; \& Gable, Shelly L. (2004). Internet use and wellbeingin adolescence. Journal of Social Issues, 58(1), 75-90. Retrieved March 16,2008, from http://web.ebscohost.com

7. Hinduga , S. and Patchini, J.W., 2007. Personal information of adolescents on the internet. A quantitative content analysis of My space. Journal of adolescence 1:1-21

8. American Psychologist, 53(9), 1017-1031. Retrieved April 11, 2008, from http://search.ebscohost.com

9. Lenhart, Amanda; Purcell, Kristen; Smith, Aaron, \&Zickuhr, Kathryn (2010).Writing, Technology and Teens. Pew Internet \& American Life Project. Retrieved fromhttp://pewinternet.org/Reports/2010/Social-Media-andYoung-Adults.aspx

10. Livingstone, Sonia, \&Helsper, Ellen (2007). Gradations in digital inclusion: Children,young people and the digital divide. New Media \& Society, 9(4), 671-696. Retrieved April 26, 2008, from http://nms.sagepub.com 